\title{
DEVELOPMENT AND VALIDATION OF A STABILITY-INDICATING RELATED SUBSTANCES OF TRANDOLAPRIL BY RP-HPLC AND ITS DEGRADATION
}

\author{
CHALLA SUDHEER REDDY ${ }^{*}$, B. TIRUMALESWARA RAO ${ }^{1}$
}

1Department of Chemistry, Vikas PG College, Vissannapeta, Andhra Pradesh, India 521215

Email: sudheer192020@gmail.com

Received: 19 May 2021, Revised and Accepted: 15 Jul 2021

\section{ABSTRACT}

Objective: A validated stability-indicating RP-HPLC method for Trandolapril was developed by separating its related impurities.

Methods: By using Waters HPLC e-2695 quaternary pump with a PDA detector of 2998 instrument, the chromatographic separation of Trandolapril and its related impurities was achieved on the column of Agilent eclipse $C_{18}(150 \times 4.6 \mathrm{~mm}, 3.5 \mu)$ using gradient elution with a buffer containing 0.1 percent formic acid and acetonitrile as a mobile phase with a flow rate of $1 \mathrm{ml} / \mathrm{min}$ at ambient temperature. A detector wavelength of $213 \mathrm{~nm}$ utilizing the PDA detector was given in the instrumental settings. The linearity was studied between the concentration range of $4-60 \mu \mathrm{g} / \mathrm{ml}$ of Trandolapril and $0.5-7.5 \mu \mathrm{g} / \mathrm{ml}$ of imp-E, imp-A, imp-B and 0.7-10.5 $\mathrm{g} / \mathrm{ml}$ of imp-D were injected with a run time of 17 min. Validation of the proposed method was carried out according to an International Conference on Harmonization (ICH) guidelines.

Results: LOD and LOQ for the Trandolapril and its impurities were established with respect to test concentration. The plotted calibration curves were linear with a regression coefficient of $\mathrm{R}^{2}>0.999$, which indicates that the linearity was within the limit. As a part of method validation, the parameters like specificity, linearity, accuracy, ruggedness, robustness were determined and the results were found to be within the allowable limit.

Conclusion: The method developed was found to be applicable to routine analysis and to be used for the measurement of active pharmaceutical ingredients (i. e, Trandolapril and its related impurities). Since there is no HPLC method reported in the literature for the estimation of Trandolapril and its related impurities; there is a need to develop quantitative methods under different conditions to achieve improvement in specificity, selectivity etc.

Keywords: Trandolapril, Related impurities, HPLC, Development, Validation

(C) 2021 The Authors. Published by Innovare Academic Sciences Pvt Ltd. This is an open-access article under the CC BY license (https://creativecommons.org/licenses/by/4.0/) DOI: https://dx.doi.org/10.22159/ijap.2021v13i5.42113. Journal homepage: https://innovareacademics.in/journals/index.php/ijap

\section{INTRODUCTION}

Trandolapril is an ACE inhibitor $[1,2]$ used to treat high blood pressure $[3,4]$. It may also be used to treat other conditions. Side effects reported for trandolapril include nausea, vomiting, diarrhea, headache, dry cough, dizziness or lightheadedness when sitting up or standing, hypotension [5], or fatigue [6]. Patients also on diuretics [7] may experience an excessive reduction of blood pressure after initiation of therapy with trandolapril. It can reduce potassium loss caused by thiazide [8] diuretics and increase serum potassium when used alone. Therefore, hyperkalemia $[9,10]$ is a possible risk. Increased serum lithium levels can occur in patients who are also on lithium. Trandolapril is teratogenic [11] (US: pregnancy category D) and can cause birth defects and even death of the developing fetus. The highest risk to the fetus is during the second and third trimesters. When pregnancy is detected, trandolapril should be discontinued as soon as possible. Trandolapril should not be administered to nursing mothers. Combination therapy with paricalcitol and trandolapril has been found to reduce fibrosis $[12]$ in obstructive uropathy $[13,14]$. Trandolapril is a prodrug that is de-esterified to trandolaprilat. It is believed to exert its antihypertensive effect through the renin-angiotensin-aldosterone system [15, 16]. Trandolapril has a half-life of about $6 \mathrm{~h}$, and trandolaprilat has a half-life of about $10 \mathrm{~h}$. Trandolaprilat has about eight times the activity of its parent drug. About one-third of trandolapril and its metabolites [17] are excreted in the urine [18, 19], and about twothirds of trandolapril and its metabolites are excreted in the feces. Serum protein binding of trandolapril is about $80 \%$. Trandolapril acts by competitive inhibition of the angiotensin-converting enzyme (ACE), a key enzyme in the renin-angiotensin system, which plays an important role in regulating blood pressure. So, we developed a method for the estimation of Trandolapril by using RP-HPLC.

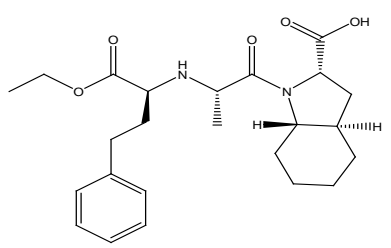

A

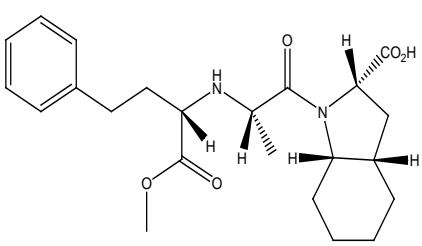

B

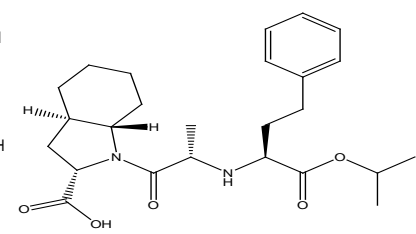

C

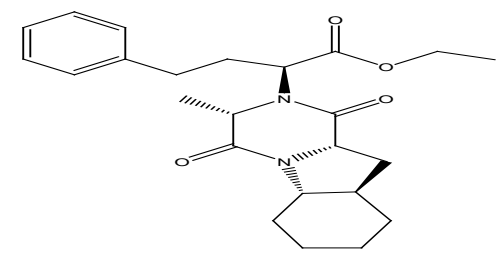

D

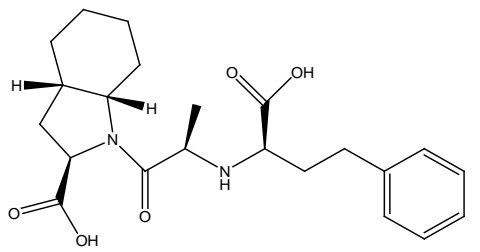

E

Fig. 1: Chemical structures of (A) Trandolapril (B) Impurity-A (C) Impurity-B (D) Impurity-D (E) Impurity-E 


\section{MATERIALS AND METHODS}

\section{Chemicals}

Acetonitrile, HPLC-grade orthophosphoric acid, water were purchased from Merck India Ltd, Mumbai, India. Candila health care ltd, Ahmedabad, India provided the reference criteria for Trandolapril and its related impurities.

\section{The instrumentation}

Waters alliance liquid chromatography (model e-2695) monitored with empower 2.0 data handling system and a detector of photodiode array (model 2998) [20] was used for this study.

Preparation of mobile phase-A: $1 \mathrm{ml}$ of formic acid is dissolved in $1 \mathrm{lt}$ of HPLC grade water and filter through $0.45 \mu$ filter paper.

\section{Mobile Phase-B: Acetonitrile}

\section{Optimization of mobile phase}

Different trails have been done, different buffers and different mobile phases were used to develop the method. In all trails, peaks are not separated properly. Finally, for the proposed method, all the peaks are separated and the entire suitability conditions are within the limit.

\section{Table 1: Gradient program}

\begin{tabular}{lll}
\hline Time (min) & Mobile phase-a & Mobile phase-b \\
\hline 0.00 & 80 & 20 \\
5 & 50 & 50 \\
7 & 20 & 80 \\
10 & 20 & 80 \\
12 & 80 & 20 \\
17 & 80 & 20 \\
\hline
\end{tabular}

Till today there are no HPLC methods reported in the literature, So, it has more interested to develop a novel and reliable HPLC strategy for the establishment of Trandolapril and its related impurities.

\section{Chromatographic conditions}

The HPLC analysis was performed on a reverse-phase HPLC system with isocratic elution mode using a mobile phase of acetonitrile and $0.1 \%$ formic acid and Agilent eclipse $\mathrm{C}_{18}(150 \times 4.6 \mathrm{~mm}, 3.5 \mu)$ column with a flow rate of $1 \mathrm{ml} / \mathrm{min}$.

\section{Diluent}

Mobile phase was used as a diluent.

\section{Validation procedure}

The analytical parameters [21-25] such as system suitability, precision, specificity, accuracy, linearity, robustness, LOD, LOQ, forced degradation and stability were validated according to ICH Q2 (R1) guidelines.

\section{Standard stock solution}

Weigh accurately $40 \mathrm{mg}$ of Trandolapril and transferred into a 100 $\mathrm{ml}$ volumetric flask; add $70 \mathrm{ml}$ of diluent sonicated for $10 \mathrm{~min}$ to dissolve the contents make up to the mark with diluent.

\section{Sample stock solution}

Transfer $740 \mathrm{mg}$ (equivalent to $40 \mathrm{mg}$ of Trandolapril and each tablet contains $4 \mathrm{mg}$ of Trandolapril) of sample into a $100 \mathrm{ml}$ volumetric flask diluted to volume with diluent. Filter through $0.45 \mu$ nylon syringe filter.

\section{Impurity standard stock solution}

Weigh accurately $5 \mathrm{mg}$ each of imp-E, imp-A, imp-B and $7 \mathrm{mg}$ of impD into a $100 \mathrm{ml}$ volumetric flask. Add $70 \mathrm{ml}$ of diluent, sonicated to dissolve and make up.

\section{Spiked standard solution}

Transfer $5 \mathrm{ml}$ of standard stock into a $50 \mathrm{ml}$ volumetric flask, add $40 \mathrm{ml}$ of diluent and also add $5 \mathrm{ml}$ of impurity standard stock solution and makeup to the mark with diluent. Filter through $0.45 \mu$ syringe filter.

\section{Spiked sample solution}

Transfer $5 \mathrm{ml}$ of sample stock into a $50 \mathrm{ml}$ volumetric flask, add $40 \mathrm{ml}$ of diluent and also add $5 \mathrm{ml}$ of impurity standard stock solution and makeup to the mark with diluent. Filter through $0.45 \mu$ syringe filter.

\section{RESULTS AND DISCUSSION}

The main analytical challenge during the development of a new method was to separate active Pharma ingredients. In order to provide good performance, the chromatographic conditions were optimized.

\section{Method validation}

The optimized RP-HPLC validated method according to ICH guidelines in terms of system suitability, linearity, accuracy, precision and robustness.

\section{System suitability}

Device suitability was performed by injecting a spiked standard solution containing $40 \mu \mathrm{g} / \mathrm{ml}$ of Trandolapril, $5 \mu \mathrm{g} / \mathrm{ml}$ each of imp-E imp-A, imp-B and $7 \mu \mathrm{g} / \mathrm{ml}$ of imp-D in six replicates. The results show that the machine fitness parameter is within the limit provided by ICH [26]. The results were shown below.

Table 2: Results of system suitability

\begin{tabular}{lll}
\hline $\begin{array}{l}\text { System suitability } \\
\text { parameter }\end{array}$ & $\begin{array}{l}\text { Acceptance } \\
\text { criteria }\end{array}$ & $\begin{array}{l}\text { Drug name } \\
\text { trandolapril }\end{array}$ \\
\hline USP Plate count & NLT 2000 & 51863 \\
USP Tailing & NMT 2.0 & 1.04 \\
USP Resolution & NLT 2.0 & 22.69 \\
\% RSD & NMT 2.0 & 0.82 \\
Retention Time & NLT 2.0 & 9.894 \\
\hline
\end{tabular}

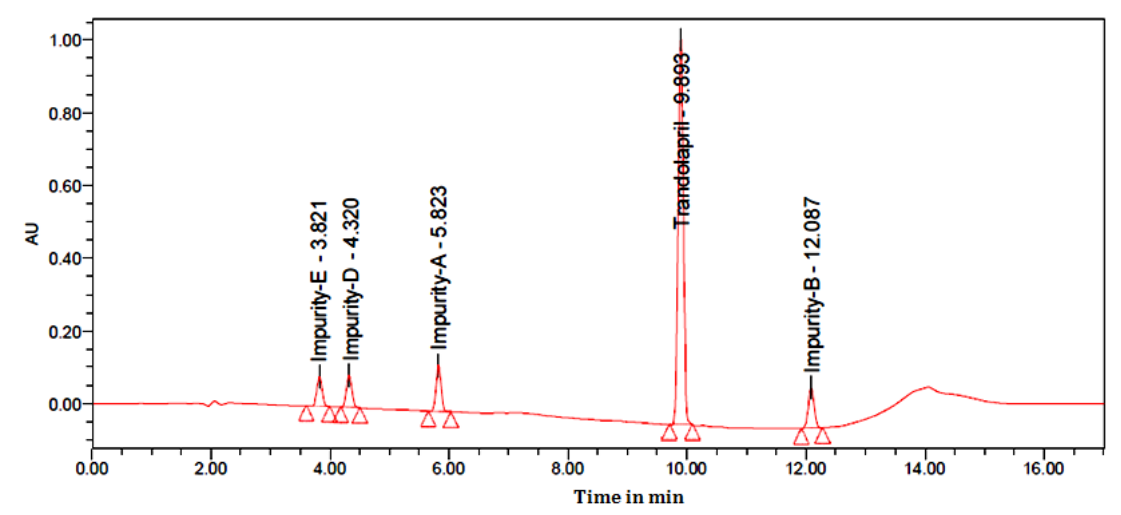

Fig. 2: Chromatogram of standard 


\section{Specificity}

In this test method, placebo, sample and standard solutions were analyzed individually to examine the interference. The below fig. shows that the active ingredient and its related substances were well separated from blank and their excipients and there was no interference of placebo with the principal peak. Hence the method is specific.

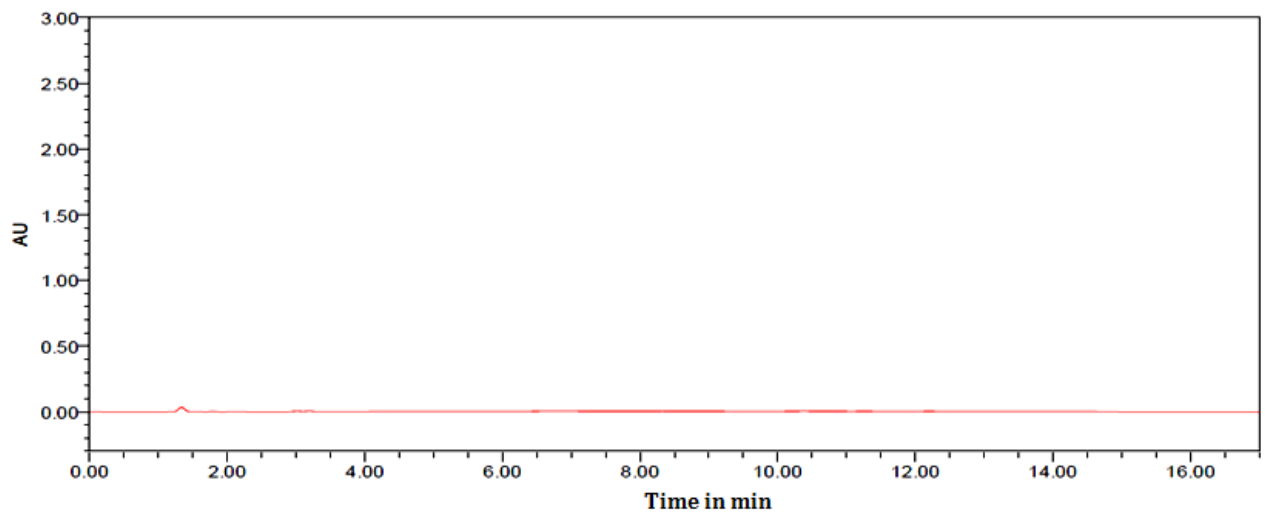

Fig. 3: Chromatogram of blank

\section{Linearity}

Linearity was calculated by plotting a calibration curve of the peak area against its respective concentration, linearity was determined. From this calibration curve, it was noticed that the curve was linear between the range of $4-60 \mu \mathrm{g} / \mathrm{ml}$ of Trandolapril and $0.5-7.5 \mu \mathrm{g} / \mathrm{ml}$ each of imp-E, imp-A, imp-B and 0.7-10.5 $\mu \mathrm{g} / \mathrm{ml}$ of imp-D. The regression equations for calibration curve was $\mathrm{Y}=147215.89 \mathrm{x}+159148.18\left(\mathrm{R}^{2}=0.9996\right)$ for Trandolapril and $\mathrm{Y}=$ $9503.01 \mathrm{x}+1281.27\left(\mathrm{R}^{2}=0.9993\right)$ for imp-E and $\mathrm{Y}=7488.75 \mathrm{x}+397.6$ $\left(R^{2}=0.9998\right)$ for imp-D and $Y=14689.54 x+1046.22\left(R^{2}=0.9993\right)$ for imp-A and $Y=14478.22 x+389.98\left(R^{2}=0.9995\right)$ for imp-B respectively.

Table 3: Linearity results of trandolapril and its impurities

A

\begin{tabular}{|c|c|c|c|c|c|c|}
\hline \multirow[t]{2}{*}{ Linearity } & \multicolumn{2}{|l|}{ Imp-E } & \multicolumn{2}{|l|}{ Imp-D } & \multicolumn{2}{|l|}{ Imp-A } \\
\hline & Conc. $(\mu \mathrm{g} / \mathrm{ml})$ & Area & Conc. $(\mu \mathrm{g} / \mathrm{ml})$ & Area & Conc. $(\mu \mathrm{g} / \mathrm{ml})$ & Area \\
\hline Linearity-1 & 0.50 & 6035 & 0.70 & 6484 & 0.50 & 9046 \\
\hline Linearity-2 & 1.25 & 13458 & 1.75 & 13311 & 1.25 & 19198 \\
\hline Linearity-3 & 2.50 & 25824 & 3.50 & 25892 & 2.50 & 37293 \\
\hline Linearity-4 & 5.00 & 50245 & 7.00 & 53572 & 5.00 & 77891 \\
\hline Linearity-5 & 6.25 & 60822 & 8.75 & 65900 & 6.25 & 91630 \\
\hline Linearity-6 & 7.50 & 71154 & 10.50 & 78762 & 7.50 & 110125 \\
\hline Slope & 9503.01 & & 7488.75 & & 14689.54 & \\
\hline Intercept & 1281.27 & & 397.6 & & 1046.22 & \\
\hline $\mathrm{CC}$ & 0.9993 & & 0.9998 & & 0.9993 & \\
\hline
\end{tabular}

B

\begin{tabular}{|c|c|c|c|c|}
\hline \multirow[t]{2}{*}{ Linearity } & \multicolumn{2}{|l|}{ Trandolapril } & \multicolumn{2}{|l|}{ Imp-B } \\
\hline & Conc. $(\mu \mathrm{g} / \mathrm{ml})$ & Area & Conc. $(\mu \mathrm{g} / \mathrm{ml})$ & Area \\
\hline Linearity-1 & 4.00 & 781724 & 0.50 & 8168 \\
\hline Linearity-2 & 10.00 & 1702135 & 1.25 & 18324 \\
\hline Linearity-3 & 20.00 & 3226387 & 2.50 & 36182 \\
\hline Linearity-4 & 40.00 & 6049599 & 5.00 & 74780 \\
\hline Linearity-5 & 50.00 & 7596589 & 6.25 & 88636 \\
\hline Linearity-6 & 60.00 & 8885327 & 7.50 & 109639 \\
\hline Slope & 147215.89 & & 14478.22 & \\
\hline Intercept & 159148.18 & & 389.98 & \\
\hline $\mathrm{CC}$ & 0.9996 & & 0.9995 & \\
\hline
\end{tabular}

\section{Accuracy}

The accuracy of the system was achieved by measuring the recovery experiments at three stages (50 percent, 100 percent and 150 percent). APIs with concentrations of 20,40 and $60 \mu \mathrm{g} / \mathrm{ml}$ of Trandolapril and 125, 250 and $375 \mu \mathrm{g} / \mathrm{ml}$ of Permethrin were prepared. For each spike stage, the test solution was injected three times and the test was performed according to the test process. The recovery results were similar to $100 \%$ and also the RSD values were less than $\pm 2 \%$. The percentage recovery, mean and relative standard deviations were determined. Recovery values shown within the desired range were correct. The results are summarized below. Accuracy findings have been shown in table 4 .

\section{Precision}

The precision of the analytical technique is the degree of proximity of the sequence of measurements obtained from multiple homogeneous mixture samplings. The accuracy of the process of the drugs was calculated by injection of six individual determinations of Trandolapril and its related substances. Method precision results were shown in table 4 and sample chromatogram was shown in fig. 5.

\section{Intraday precision}

Six replicates of a sample solution containing Trandolapril and is related substances were analysed on the same day. Peak areas were calculated, which were used to calculate mean, SD and \%RSD values. 


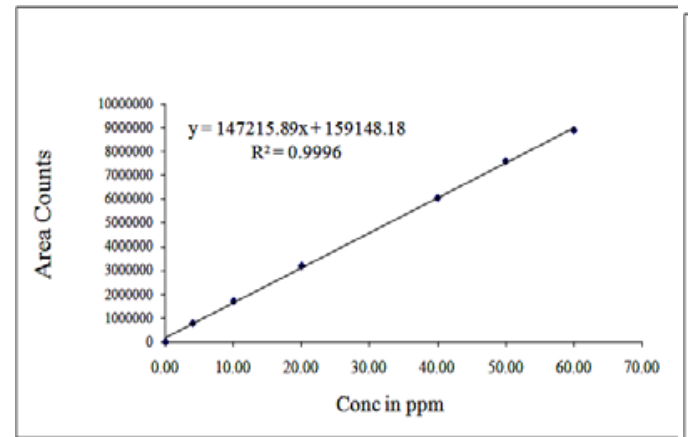

Trandolapril

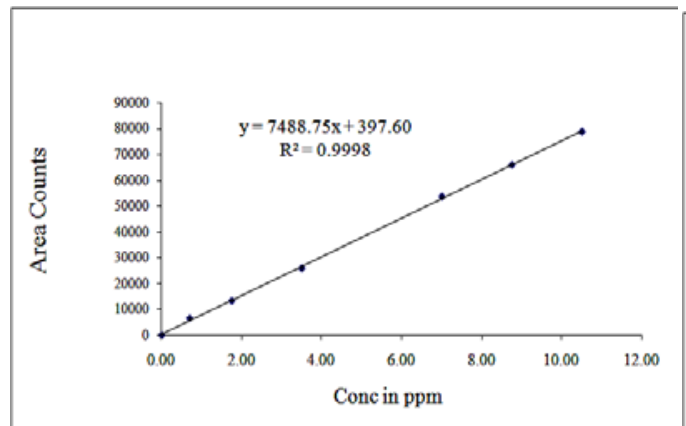

Imp-D

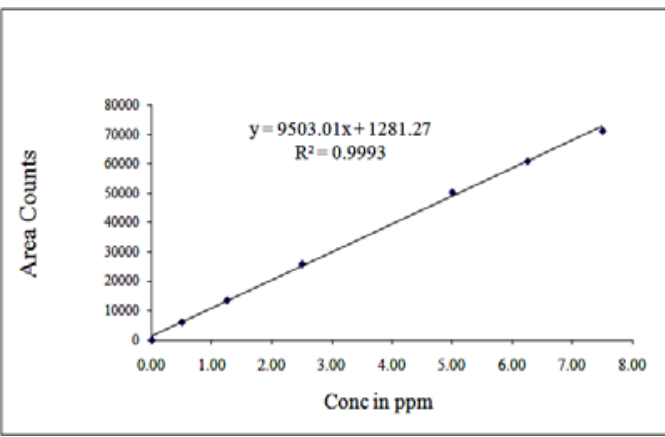

Imp-E

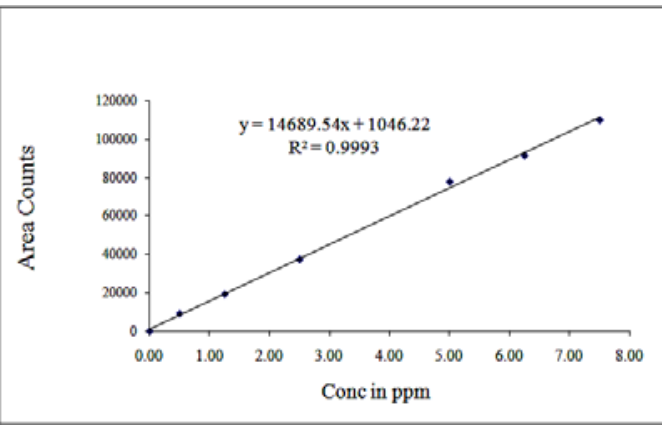

Imp-A

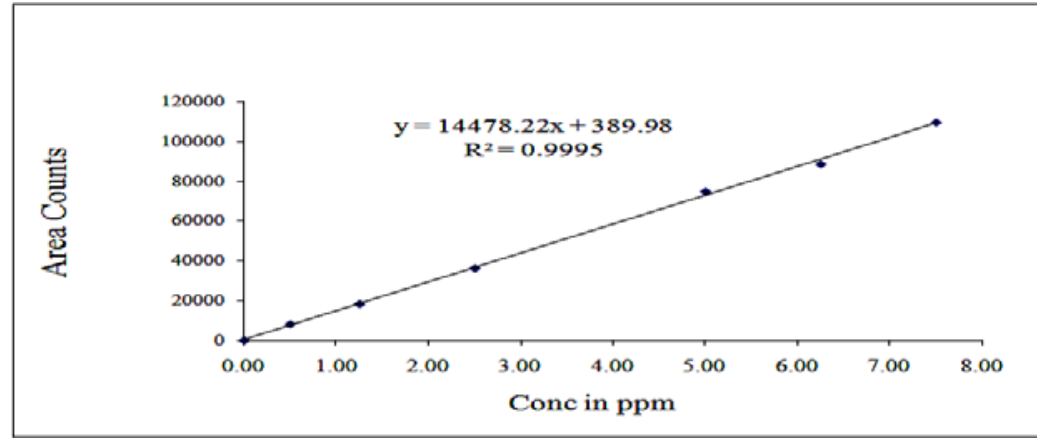

Imp-B

Fig. 4: Calibration plots of trandolapril and its related impurities

Table 4: Results of accuracy

\begin{tabular}{lll}
\hline S. No. & \% Level & Trandolapril \% recovery \\
\hline 1 & 50 & 99.82 \\
2 & 100 & 100.05 \\
3 & 150 & 99.76 \\
Mean & & 99.88 \\
Std Dev & & 0.153 \\
\hline
\end{tabular}

mean $\pm S D(n=3)$

Table 5: Intraday precision results of allantoin and permethrin

\begin{tabular}{llll}
\hline Sample No. & \% of related substances & & \\
\cline { 2 - 4 } & Spiked impurities & Total impurities & \% Purity (100-total impurities) \\
\hline 1 & 1.15 & 0.58 & 99.42 \\
2 & 1.16 & 0.62 & 99.38 \\
3 & 1.12 & 0.64 & 99.36 \\
4 & 1.24 & 0.69 & 99.31 \\
5 & 1.22 & 0.63 & 99.37 \\
6 & 1.28 & 0.61 & 99.39 \\
Average & 1.20 & 0.63 & 99.37 \\
\% RSD & 5.12 & 5.82 & 0.04 \\
\hline
\end{tabular}

mean $\pm S D(n=6)$ 


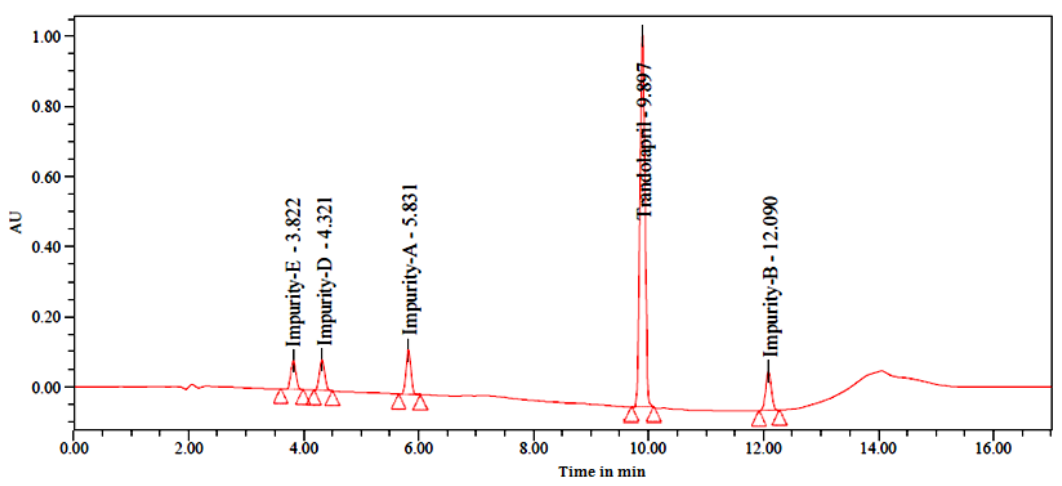

Fig. 5: Chromatogram of sample

\section{Intermediate precision}

Six replicates of the sample solution were analyzed by different researchers and different tools were checked on separate days. The peak regions used to assess the average percent of RSD values have been determined. The findings are shown in the table below.

\section{Interday precision}

Six replicates of a sample solution containing Trandolapril and its related substances were analysed on a different day. Peak areas were calculated, which were used to calculate mean, SD and \%RSD values. The present method was found to be precise as the RSD values were less than $2 \%$ and also, the percentage assay values were close to be $100 \%$. The results are given in table 6 [27].

\section{LOD and LOQ}

LOD and LOQ were determined separately using the calibration curve technique. The LOD and LOQ of the compound were measured using the developed RP-HPLC method by injecting lower and lower concentrations of the standard solution. The LOD and LOQ concentrations and their $\mathrm{s} / \mathrm{n}$ values of Allantoin and Permethrin were represented in the following table. This method is validated as per the ICH guidelines $[28,29]$.

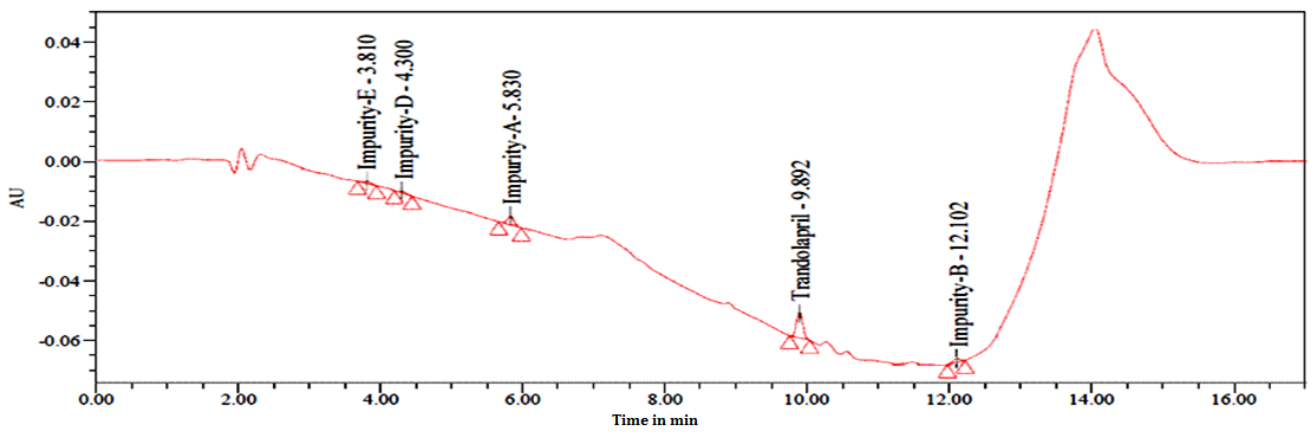

A

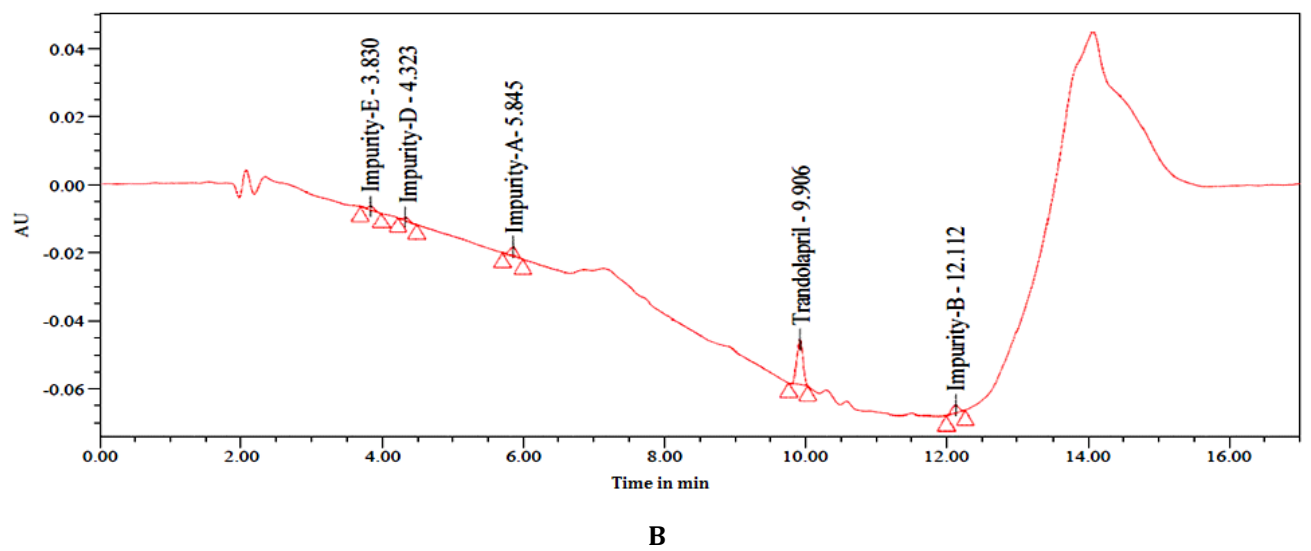

Fig. 6: Chromatogram of (A) LOD and (B) LOQ

\section{Robustness}

The conditions of the experiment were designed to measure the robustness of the intentionally changed conditions such as flow rate, mobile phase in organic percentage in all these varied conditions. Robustness results for Trandolapril and its impurities were found to be within the limit and results were tabulated in table 8 [30]. 
Table 6: Inter-day precision results

\begin{tabular}{llll}
\hline Sample No. & \% of related substances & & \\
\cline { 2 - 4 } & Spiked impurities & Total impurities & \% Purity (100-Total impurities) \\
\hline 1 & 1.19 & 0.68 & 99.32 \\
2 & 1.25 & 0.66 & 99.34 \\
3 & 1.22 & 0.59 & 99.28 \\
4 & 1.17 & 0.72 & 99.45 \\
5 & 1.13 & 0.55 & 99.38 \\
6 & 1.20 & 0.62 & 99.36 \\
Average & 1.19 & 0.64 & 0.06 \\
\hline
\end{tabular}

mean $\pm \operatorname{SD}(n=6)$

Table 7: Results of LOD and LOQ

\begin{tabular}{llll}
\hline Name & LOD conc. $(\boldsymbol{\mu g} / \mathbf{m l})$ & S/N & LOQ conc. $(\boldsymbol{\mu g} / \mathbf{m l})$ \\
\hline Trandolapril & 0.05 & 8 & 0.165 \\
Imp-E & 0.0063 & 4 & 0.0218 \\
Imp-D & 0.0088 & 5 & 0.029 \\
Imp-A & 0.0062 & 4 & 37 \\
Imp-B & 0.0061 & 4 & 0.0218 \\
\hline
\end{tabular}

Table 8: Robustness results of allantoin and permethrin

\begin{tabular}{lc}
\hline Parameter name & \% RSD \\
\cline { 2 - 3 } & Trandolapril \\
\hline Flow rate $(0.8 \mathrm{ml} / \mathrm{min})$ & 0.35 \\
Flow rate $(1.2 \mathrm{ml} / \mathrm{min})$ & 0.98 \\
Org Plus $(66: 34)(+10 \%)$ & 1.01 \\
Org Minus $(54: 46)(-10 \%)$ & 0.86 \\
\hline
\end{tabular}

Table 9: Stability results of trandolapril

\begin{tabular}{lll}
\hline Stability & Trandolapril & \\
\cline { 2 - 3 } & \% Purity & \% deviation \\
\hline Initial & 99.98 & 0.01 \\
$6 \mathrm{~h}$ & 99.36 & 0.24 \\
$12 \mathrm{~h}$ & 98.86 & 1.14 \\
$18 \mathrm{~h}$ & 98.53 & 1.47 \\
$24 \mathrm{~h}$ & 98.21 & 1.79 \\
\hline
\end{tabular}

\section{Stability}

Normal solution was kept at room temperature and $2-8^{\circ} \mathrm{C}$ for up to $24 \mathrm{~h}$. These solutions were then pumped into the system and the percent deviation from the initial to $24 \mathrm{~h}$ was measured [31]. No major variations were found and verified that the solutions were stable up to $24 \mathrm{~h}$ percentage of the assay was not quite $2 \%$. There is no effect in storage conditions for Trandolapril and its related impurities. Stability results were tabulated in table 9.

\section{Degradation studies}

Trandolapril and its related substances were subjected to various conditions of forced degradation $[32,33]$ in order to induce partial degradation of the compound. Forced degradation experiments have been performed to establish that the process is acceptable for degradation materials $[34,35]$. In addition, the studies include information on the condition under which the drug is unstable, such that the steps are also taken during formulation to prevent possible instabilities [36].

\section{Acid degradation}

Acid degradation was done by using $1 \mathrm{~N} \mathrm{HCl}$ and $15.3 \%$ Trandolapril degradation was observed.

\section{Alkali degradation}

Alkali degradation was done by using $1 \mathrm{~N} \mathrm{NaOH}$ and $15.1 \%$ of Trandolapril degradation was observed.

\section{Peroxide degradation}

Peroxide degradation was done by using $30 \%$ peroxide and $14.7 \%$ of Trandolapril degradation was observed.

\section{Reduction degradation}

Reduction degradation was done by using $30 \%$ sodium bisulphate solution and $12.4 \%$ Trandolapril degradation was observed.

\section{Thermal degradation}

Thermal degradation was done at $105{ }^{\circ} \mathrm{C}$ and $11.9 \%$ of Trandolapril degradation was observed.

\section{Hydrolysis degradation}

Hydrolysis degradation was done by using HPLC water and $10.7 \%$ Trandolapril degradation was observed.

Table 10: Forced degradation results of allantoin and permethrin

\begin{tabular}{ll}
\hline Degradation condition & Trandolapril \\
\cline { 2 - 2 } & \% purity \\
\hline Acid deg & 15.3 \\
Alkali deg & 15.1 \\
Peroxide deg & 14.7 \\
Reduction deg & 12.4 \\
Thermal deg & 11.9 \\
Hydrolysis deg & 10.7 \\
\hline
\end{tabular}

\section{CONCLUSION}

The developed method gave good results between Torsemide and its four impurities with a run time of $17 \mathrm{~min}$, high efficiency and 
complies with modified SST specifications of USP. The utilization of Agilent eclipse $\mathrm{C}_{18}$ column within the present work has shown better elution of analytes with good resolution, improved plate count and tailing. Therefore the $\mathrm{C}_{18}$ columns are often wont to achieve high specificity in a shorter time of study of Trandolapril as per ICH Q 3A $\left(\mathrm{R}_{2}\right)$ guidelines. The proposed method was found to be simple, precise, accurate, linear, robust and rapid for simultaneous determination and quantification of Trandolapril and its impurities. The sample recovery was in good agreement with their respective label claims suggested non-interference within the estimation. Hence, the technique is often easily and conveniently adopted for routine analysis of Trandolapril in the combined dosage form.

\section{ACKNOWLEDGEMENT}

I thankful to Shree Icon Pharmaceutical Laboratories for providing laboratory facilities to finish this research work.

\section{FUNDING}

Nil

\section{AUTHORS CONTRIBUTIONS}

All authors have contributed equally.

\section{CONFLICTS OF INTERESTS}

Author declares that there have been no conflicts of interest.

\section{REFERENCES}

1. Van Vark LC, Bertrand M, Akkerhuis KM, Brugts JJ, Fox K. Angiotensin-converting enzyme inhibitors reduce mortality in hypertension: a meta-analysis of randomized clinical trials of renin-angiotensin-aldosterone system inhibitors involving 158,998 patients. Eur Heart J 2012;33:2088-97.

2. Augenstein, Vedra A, Heniford B Todd, Sing, Ronald F. intestinal angioedema induced by angiotensin-converting enzyme inhibitors: an underrecognized cause of abdominal pain. J Am Osteopath Assoc 2013;113:221-3.

3. Musini VM, Gueyffier F, Puil L, Salzwedel DM, Wright JM. Pharmacotherapy for hypertension in adults aged 18 to 59 y. Cochrane Database Syst Rev 2017;8:CD008276.

4. Arguedas, Jose Agustin, Leiva, Viriam, Wright, James M. Blood pressure targets in adults with hypertension. Cochrane Database Syst Rev 2020;12:CD004349.

5. Freeman Roy, Abuzinadah, Ahmad R, Gibbons, Christopher, Jones, et al. Orthostatic hypotension: JACC state-of-the-art review. J Am Coll Cardiol 2018;72:1294-309.

6. Shen J, Barbera J, Shapiro CM. Distinguishing sleepiness and fatigue: focus on definition and measurement. Sleep Med Rev 2006;10:63-76.

7. Rejnmark L, Vestergaard P, Pedersen AR, Heickendorff L, Andreasen F, Mosekilde L. Dose-effect relations of loop-and thiazide-diuretics on calcium homeostasis: a randomized, doubleblinded latin-square multiple cross-over study in postmenopausal osteopenic women. Eur J Clin Invest 2003;33:41-50.

8. Magaldi, Antonio J. New insights into the paradoxical effect of thiazides in diabetes insipidus therapy. Nephrol Dial Transplant 2000;15:1903-5.

9. Smellie, W Stuart A. Spurious hyperkalemia $\mathrm{Br}$ Med J 2007;334:693-5

10. Kovesdy CP.Updates in hyperkalemia: outcomes and therapeutic strategies. Rev Endocr Metab Disord 2016;18:41-7.

11. Bellinger DC. Teratogen update: lead and pregnancy. Birth Defects Res (Part A) Clin Mol Teratol 2005;73:409-20.

12. Chute, Michael, Aujla, Preetinder, Jana. The non-fibrillar side of fibrosis: contribution of the basement membrane, proteoglycans, and glycoproteins to myocardial fibrosis. Cardiovasc Dev Dis 2019;6:35.

13. Woodford HJ, George J. Diagnosis and management of urinary infections in older people. Clin Med 2011;11:80-3.

14. Simerville, Jeff A. Urinalysis: a comprehensive review. Am Fam Physician 2005;71:1153-62.

15. Kumar R, Singh VP, Baker KM. The intracellular renin-angiotensin system in the heart. Curr Hypertens Rep 2009;11:104-10.
16. Brown MJ. Success and failure of vaccines against reninangiotensin system components. Nat Rev Cardiol 2009;6:639-47.

17. Obach R Scott, Esbenshade, Timothy A. Pharmacologically active drug metabolites: Impact on drug discovery and pharmacotherapy. Pharmacol Rev 2013;65:578-640.

18. Yang PJ, Pham J, Choo J, Hu DL. Duration of urination does not change with body size. Proc Natl Acad Sci USA 2014;111:11932-7.

19. Rose C, Parker A, Jefferson B, Cartmell E. the characterization of feces and urine: a review of the literature to inform advanced treatment technology. Crit Rev Environ Sci Technol 2015;45:1827-79.

20. Cijo M Xavier, Kanakapura Basavaiah. RP-UPLC development and validation of metformin hydrochloride in pure drug and pharmaceutical formulations. World J Pharm Pharm Sci 2015;4:1649-68.

21. Shalini K, Ilango K. Development, evaluation and RP-HPLC method for simultaneous estimation of quercetin, ellagic acid and kaempferol in a polyherbal formulation. Int J Appl Pharm 2021;13:183-92.

22. Sri Girija K, Bikshal Babu K, Venkateswara Rao A. A new highperformance liquid chromatography method for the separation and simultaneous quantification of eptifibatide and its impurities in pharmaceutical injection formulation. Int J Appl Pharm 2021;13:165-72.

23. VLN Balaji Gupta T, Venkateswara Rao B, Kishore Babu B. RPHPLC (stability-indicating) based assay method for the simultaneous estimation of doravirine, tenofovir disoproxil fumarate and lamivudine. Int J Appl Pharm 2021;13:153-9.

24. Murali Krishnam Raju P, Venkata Narayana B, Shyamala P, Srinivasu K, HSN Raju D. A validated RP-HPLC method for impurity profiling of Sodium nitroprusside in an injection dosage form. Int J Appl Pharm 2021;13:160-9.

25. Sanathoiba Singha L, Srinivasa Rao T. Development and validation of an RP-HPLC method for the determination of ulipristal acetate in the pharmaceutical dosage form. Asian J Pharm Clin Res 2021;14:83-9.

26. Asha Eluru, Surendra Babu K. A study of method development, validation and forced degradation for simultaneous quantification of povidone lodine and ornidazole in bulk and pharmaceutical dosage form by using RP-HPLC. IJPSR 2021;12:1217-22.

27. Malathi S, Devakumar D. Development and validation of RPHPLC method for the estimation of escitalopram oxalate and flupentixol dihydrochloride in combined dosage form and plasma. Int J Pharm Pharm Sci 2021;13:61-6.

28. International Conference on Harmonization (ICH). Harmonized tripartite guideline validation of analytical procedures: Text and methodology Q2 (R1). Geneva: IFPMA, Switzerland; 2005.

29. Ravichandran V, Shalini S, Sundaram KM, Rajak H. Validation of analytical methods-strategies and importance. Int J Pharm Pharm Sci 2010;2:18-22.

30. Raviteja G, Rambabu K. A study of development and validation of a method for simultaneous estimation of cidofovir and famciclovir using RP-HPLC. Int J Res Pharm Sci 2020;11:7878-84.

31. Vijayakumari M, Balasekhar Reddy Ch. Stability indicating validated HPLC method for the determination of zanubrutinib in bulk and pharmaceutical dosage form. Asian J Pharm Clin Res 2020;13:159-62.

32. Mohinish Sahai, N Devanna. Validated stability-indicating HPLC approach for quantifying tricholine citrate and cyproheptadine simultaneously in syrup forms. Int J Appl Pharm 2021;13:207-13.

33. Abdul Raziq, Syed Umer Jan. Relative comparison of stability and degradation of methylcobalamin tablets of different brands at different storage settings. Int J Appl Pharm 2021;13:171-5.

34. Rajakumari R, Sreenivasa Rao S. Stress degradation studies and development of a validated RP-HPLC method for determination of tiagabine in the presence of its degradation products. Int J Pharm Pharm Sci 2016;8:230-6.

35. Charu Pandya P, Sadhana Rajput J. Development and validation of stability-indicating method RP-HPLC method of acotiamide. Int J Pharm Pharm Sci 2018;10:1-8.

36. Birva Athavia A, Zarna Dedania R. Stability indicating HPLC method for determination of vilazodone hydrochloride. Int J Curr Pharm Res 2017;9:123-9. 